\title{
Banks' Vulnerabilities to Money Laundering Activities
}

\section{Abstract \\ Purpose}

This paper provides insights as to why money laundering persists in banks, and their weaknesses as gatekeepers.

\section{Design/methodology/approach}

This paper contextualizes the design and proliferation of AML measures; investigates the different manners of conceptualizing them; and provides insights pertaining to probable limitations of these measures. The paper relies on primary data from statutes and secondary data from published sources.

\section{Findings}

The paper's findings suggest that competitive pressures, shareholders returns imperative, and lucrative misaligned incentives for management contributed to weaknesses in effective compliance in banks.

\section{Practical implications}

Insights drawn from this paper reinforces the notion that banks need to seriously review their business approaches, as well as their roles as gatekeepers.

\section{Social implications}

Given the slew of corporate scandals and other materially harmful misjudgments in moneylaundering compliance, banks might need to seriously review their role and obligations in the economy.

\section{Originality/value}

Much has been said about money-laundering activities enabled by the banking sector. This paper contributed to insights as to why they persist despite AML rules, and what measures could be further taken to enhance compliance effectiveness.

\section{Keywords}

Anti-money laundering, bitcoin, European banks, financial disruptions, jurisdictional risk, virtual currencies, whistleblowing

\section{Type}

General review

\section{Introduction}

Three recent banking case incidents in Europe sparked money-laundering concerns in the region and across the world. The first involved a highly respected bank from Denmark (Schwartzkopff, 2019). The second involved a generally highly respected global mega German bank that has links with the Danish bank as its US subsidiary is said to keep Danske's shady billions flowing (Harding, 2019). The third involved a large global Dutch bank that pad a $€ 775$ million settlement due to serious shortcomings in money laundering prevention (Jaeger, 2018). To put in context, money laundering persists as a key operational risk for banks globally, but European banks seemed to be overrepresented in the steady flow of cases of banks disciplined for anti-money laundering and sanction violations (Edwards et al, 2018).

The revelations of these three large money-laundering activities helped to justify recent updated EU anti-money laundering (AML) directives, the most recent of which are the EU's $5^{\text {th }}$ Anti-Money Laundering Directive (5AMLD) Directive that came into force in July 2018 (Marria, 2018; Osborne, 2018), and the $6^{\text {th }}$ Anti-Money Laundering Directive (6AMLD) requiring member states to transpose this into national law by 3 December 2020 (Europa, 2018). However, these also triggered the question as to whether the updated European AML rules would be adequate to mitigate money- 
laundering activities of this scale in banks, and more so in other entities in the financial services sector, especially the fast-emerging virtual banks (Weld, 2011); and those others transacting in digital assets (Anagnostpoulos \& Kabeega, 2019; Groysman, 2018).

Accordingly, money-laundering risks could become enhanced, given the magnitude of the estimated sum of US\$500 billion to US\$1 trillion money laundered worldwide (Basel Institute of Governance (BIG), 2018). The problem could be compounded as crypto assets creep significantly into the mainstream. This article argues that effective gatekeeping by banks against these potential money laundering risks could be achieved through the strengthening of their AML compliance systems, and holding their senior officials accountable with sterner punitive measures (Gegenheimer, 2019).

\section{A brief sketch of money-laundering activities in banks AML laws}

US Position

Money laundering refers to the processing of criminal proceeds to camouflage their illegal origin (Financial Action Task Force (FATF), 2019). Criminal activities generate high profits, such that the groups involved must finds ways to control these funds without attracting attention to the underlying activities involved. Perpetrators achieved this by camouflaging the sources, changing the form, or transferring the funds to destinations that are likely to attract less attention (FATF, 2019). Known extraordinarily apt tools used by money launderers across the world include the use of high value physical commodities, real estate projects, and via some banks (Maximillian \& Teichmann,2016).

Money-laundering activities in banks in modern day terms do not surprised most business people, as the menace for example surfaced in a big scale in late 1970s involving the then notorious BCCI scandal (Beaty \& Gwynne, 2004). Hence, it unsurprisingly that most banks endeavor to protect their interests for being excessively used in money laundering (Agarwal, 2003). Anti-money laundering laws in the US include the Bank Secrecy Act of 1970, which is the main AML statute; and the betterknown USA Patriot Act of 2001.

Gatekeepers are entities entrusted with the duty to prevent misconduct by withholding support (Coffee Jr, 2006; Kraakman, 1986). AML gatekeeping functions (Vermeulen, 2018) now increasingly extend to banks because of the obligations imposed on them to report suspicious transactions (Lakatos \& Hanchet, 2007). Linked to this is the threat of corruption risk or the risks that financial entities could be involved in forms of bribery and/or conflicts of interest that compromise the integrity of, and trust in the entities concerned, or in the financial markets. Banks accordingly have instituted measures to prevent themselves from processing corrupt payments.

Some settlements with foreign-owned banks involving substantial fines or forfeitures have been premised on alleged sanctions violations additional to BSA violations. In the 1980s though there were two instances of BSA prosecutions of banks. Banks in general opted for settlements in relation to money laundering, but these have been premised on allege breach of the BSA, and not breach of money laundering offences. Since early 2000 , more than two dozen banks pled guilty or agreed to criminal settlements with the DOJ on alleged breaching of BSA rules on money laundering, like failures to file SARs or the upkeep of sufficient AML routines (Noonan \& Cohen, 2019; ESRB, 2015).

Despite its world dominance in financial services, the US is said to be not fully in compliance with FATF regulations. These include the absence of reliable corporate registries for confirmation of factual beneficial information provided by customers, the absence of imposition of AML requirements on gatekeepers consistent with FSTF guidance, the absence of updated requirement for investment advisers, lack of attorneys oversight, and the absence of imposition of requirements 
on property agents, and trust and company services providers, as well as addressing the matters of domestic politically-exposed persons (Nahee, 2018; Monroe, 2016; FATF, 2016; Huang, 2015).

Meanwhile, the US opposed the inclusion of American Samoa, Guam, Puerto Rico and the US Virgin Islands on the EU's list of high-risk jurisdictions as a consequence of deficiencies in their AML/CFT regimes. The US counter-claimed that that the EU methodology is flawed, but more importantly the US confirmed that the commitments and actions of the US in implementing the FATF standards extend to all US territories (US Treasury, 2019).

\section{EU position}

Europe's rules against money-laundering are contained in its various EU anti-money laundering directives (Borlini \& Montanaro, 2017). The EU adopted its $1^{\text {st }}$ AMLD in 1990 so as to prevent the misuse of the financial system for the aim of money laundering (Alexander, 1998). This legislation was constantly revised so as to mitigate risks pertaining to money laundering and terrorist financing. The EU updated to a more modernized regulatory framework through the $4^{\text {th }}$ AMLD (EU) 2015/849 (EC, 2019).

The $5^{\text {th }}$ AMLD is largely designed in response to the revelations of the Panama Papers. The legislation adopted in April 2018 provides enhanced powers of EU Financial Intelligence Units (FIUs) and deployment of beneficial ownership registers for enhanced transparency (Marria, 2018), risk prevention in the use of virtual currencies, enhanced safeguards for financial transactions to and from high-risk third countries, enhanced access to centralized bank account registers, and the ensuring of central data retrieval systems in all EU member states (Corsoni-Husain \& Savvides, 2018). The $5^{\text {th }}$ AMLD's imprecise wording for virtual currencies and their limited scope might, however, contribute to legal uncertainty and loopholes for relevant entities where Member States transpose it verbatim (Haffke, Fromberger \& Zimmermann, 2019; De Vido, 2019).

The EC initiated the $6^{\text {th }}$ AMLD for transposition by Member States by 2020 under the belief that even with the $5^{\text {th }} A M L D$, the measures to tackle money laundering were still not sufficiently comprehensive or coherent. This in particular is attributed to national differences in the definition, scope and sanctioning of money laundering offences, and importantly to the need for enhanced level of cooperation between national police forces (O'Connor, 2019; 2018).

The legislation ergo seeks to combat money laundering through criminal law, via the enabling of more efficient and quicker cooperation between competent authorities, through ensuring compatibility with FTF initiatives, and by ensuring that the definition of criminal activities which predicate money laundering offences is sufficiently uniform in all Member States, and including addressing risks posed by the use of virtual currencies (EU, 2018). Hence, aside from the deployment of a harmonized definition of a predicate crime, criminal liability would henceforth be extended to legal persons including persons acting on their behalf, the use of investigative tools and rules to ascertain Member State jurisdictions when the offence crosses borders (Brockdorff \& Gerybaite, 2019; O'Connor, 2019). This approach aligns with the wider trend of failure to prevent economic crimes (Nakajima, 2018). Criminal charges accordingly could also be levied against perpetrators, inciters or accessories in those money laundering offences undertaken for the benefit of the corporation as a whole (O'Connor, 2018).

\section{Global initiatives}

Acknowledging that the combat against money laundering cannot be fought in isolation, a global organization known as the Financial Action Task Force (FATF) was set up at the G-7 Summit in Paris in 1989. FATF's main attention is member country adoption of its anti-money laundering compliance recommendations and the monitoring of members' compliance to its more than forty recommendations commonly referred to as the global standards for AML/CFT. The IMF and the World Banks also joined in the global initiatives against money-laundering as both are equally 
concerned over the destructive impacts these activities have on the economic, political, and social fabric of impacted economies

\section{Money laundering alleged breaches in three selective European banks}

Three European banks are selected for case analysis on the basis of their magnitude and controversies. These are obviously more than these three examples (Edwards et al, 2018). Danske Bank (DB)

Foremost, DB is a Danish bank that is not supervised by the SSM as Denmark is not part of the EU Banking Union. Its branch in Estonia is supervised by Estonia's Financial Supervisory Authority (Finantsinpeksioon) as the host supervisor as per the Capital Requirements Directive (CRD). This means that for money laundering issues, the home supervisor is fully responsible for prudential supervision, including internal control systems. DB conceded that it was the centre of an unprecedented laundering scandal for failure to screen thousands of clients in its Estonian branch, especially when much of the US\$230 billion mainly Russian money flowing through those accounts were suspicious (Schwartzkopff, 2019). This current episode exposed potential loopholes in EU banking legislation.

DB was alleged to have been insufficiently effective in preventing its branch in Estonia between 2007 and 2015 from potentially being deployed for money laundering arising from critical deficiencies in governance and internal controls. The Danish Financial Services Authority (FSA) directed the bank to expand its capital requirements by DKK10 billion as a buffer for increased compliance and reputational risk.

DB's commissioned independent report (Bruun \& Hjejle, 2018) concluded that series of deficiencies in the bank's governance and control systems enabled suspicious transactions in its Estonia branch. The report suggests that the said branch had a large number of non-resident customers in Estonia undertaking large prohibited transactions that were only partially reported to the authorities; while the branch's control functions did not have a satisfactory degree of independence from the main organization (Bruun \& Hjejle, 2018). The report stressed that of the 6,200 accounts examined, most were linked to clients registered in Russia, Britain, and the British Virgin Island with the vast majority of these deemed suspicious (Neely, 2018). Further, this said branch operated too independently from the rest of the DB group and without sufficient control and management focus from the operational centre thereby contributing to the delay in problems detection and rectification of shortcomings (Nielsen, 2018).

Whistleblowing disclosures alleged that the inadequate understanding of the risk meant that the issues were generally reported internally with confirmations that things were within control, while possible collusion between customers and employees at the branch was left undetected or unchecked (Wilkinson, 2018; 2018a). Whistleblowing further suggests that AML at DB involved at least ten banks active in different economies, eight Member States' banks and in particular large US banks, where some $80 \%-90 \%$ of money flowing through DB ended up in dollars, exiting through US correspondent banks into the financial system (Wilkinson, 2018; 2018a). These disclosures induced a US pension fund class action suit against DB and its former four top executives alleging them of defrauding investors and inflating its share price by hiding and failing to stop widespread money laundering at its Estonian branch (Stempel, 2019).

The DB scandal exposed the limits of the EU supervisory framework, where under EU law, various competent Danish authorities were responsible for the supervision of Danish credit institutions inclusive of their internal control systems as whole. With respect of incoming branches of EU credit institutions doing business in Estonia, the Estonian financial supervisory institution has limited 
authority, but in exercising its responsibilities and by its actions ended the significant moneylaundering risks arising from the activities of the Estonian branch of DB in 2014/2015.

The EC responded to these issues by requesting in September 2018 the European Banking Authority (EBA) to investigate a possible violation of EU law or non-deployment of EU law by both the competent authorities in Estonia and Denmark (EC, 2018). The EC raised concerns as to whether the actions of the Danish supervisor being the one responsible for the compliance with group-wide AML/CFT policies and procedures were sufficiently clear or transparent, and that it carried out effective supervision of the DB group. Doubts were further raised as to whether information exchanges between the two said supervisors were relevant and adequate.

The General Data Protection Regulation (GDPR) in particular while protecting clientele privacy also implies that nothing could prevent blacklisted clients from migrating between accounts. This raised the support for entertaining the idea of enabling banks to share clientele information like SARs before confirmation of illegal activities by the police (Zagaris, 2019). On the other hand, there is the unwanted risk of harming the interest of potentially innocent people. In any event, taking cognizance of the magnitude of the problem, the ECB and national authorities supervising financial institutions' compliance with EU AML obligations in close cooperation with the EC and the European Supervisory Authorities reached agreements on actions that have to be taken when a weak link is located in the system and what precise information would be exchanged to enable efficient and timely intervention (Zagaris, 2019).

\section{ING Bank}

Ing Bank (IB), the largest Dutch bank directly supervised by the ECB was fined $€ 675$ million regarding diligence shortcomings to prevent money laundering and financial crimes between 2010 to 2016 , and $€ 100$ million for disgorgement (ING, 2018). Prosecutors alleged that during the period concerned, IB's Netherlands branch (ING NL) failed to sufficiently implement the Dutch AML/CTF Act as it had not addressed known weaknesses in customer due diligence policies and to report suspicious transactions (Treanor, 2018). The Dutch Central Bank had on several occasions warned the bank of these suspicious transactions and to resolve weaknesses in its AML policy, especially the inadequate vigour given to its AML system. The bank's own internal investigation had also revealed various AML failures, including missing or incomplete files on customer due diligence.

Dutch authorities commenced investigating IB after prior knowledge of criminally investigated corporations and individuals holding accounts with the bank. The authorities cited at east four cases where ING NL accounts were abused (Parker, 2018; Treanor, 2018). One example pertained to laundering of $€ 150$ million by a women's underwear trader that had little to do with the lingerie trade, and ergo suspicious. Moreover, individuals holding the accounts for the trader had been suspected for money laundering before. Another involved a telecommunications company where ING accounts were used to facilitate bribery in tens of millions for politically exposed persons.

The Dutch Prosecution Service revealed several compliance risk management flaws (Jaeger, 2018). These included incomplete or missing customer due diligence (CDD) files, and missing identification and verification details of clients and their ultimate owners including politically exposed persons. There were also various instances of failures to exit business relationships in timely fashions, where CDD was undertaken subsequent to customer acceptance and the relationship terminated only thereafter. There were also various instances of incorrect assigned risk classifications culminating in the failure to have the CDD done or having them done late.

As such, IB failed to have its CDD review process in order as CDD did not take place within the stipulated timeframe or subsequent to particular risk events (Jaeger, 2018). The bank's posttransaction monitoring system was also inadequate. This pertained to shortcomings concerning both the generation of alerts and the examination and handling of these red flags. 
Even when unusual transactions were recognized, these were on occasions not reported to the Financial Intelligence Unit (FIU), or reported too late. Incorrect classification of clients that caused high risk clients to be classified into a lower risk customer segment aggravated this problem. These inadequacies were the outcomes of insufficient investments in its transaction monitoring system and in the personnel responsible for signaling red flags and undertaking CDD investigations (Jaeger, 2018).

The compliance department was also understaffed and inadequately trained resulting in the limited signaling of money laundering potential cases. However, no employees were criminally implicated in these failings, or found to have received personal gains. Importantly, the shortcomings were not attributable to individual persons, but instead suggested shortcomings at all responsible management levels like the business compliance and control functions. As compliance to the money laundering rules vested in different parts of the management functions, there was the absence of overseeing compliance as a whole (Jaeger, 2018).

These unresolved failings contributed to the bank missing out potential money laundering signals from 2010 to 2016 in particular. IB has responded to these through undertaking several initiatives to further strengthen its risk compliance management system, and these included the implementation of KYC efforts and enhanced client-activity monitoring capabilities (Jaeger, 2018). On the external front, the bank collaborates with the Financial Expertise Centre, the Dutch Central Bank and the Dutch Banking Association to harmonize initiatives and insights in the combat against financial crimes.

\section{Deutsche Bank}

Deutsche Bank (DB) was fined $€ 585$ million in 2017 by the European competent authority. The settlement included an undertaking to carry out various remedial initiatives. Investigations and settlements issues with the US DOJ remained unsettled. The bank sees a high risk that US and UK regulators would take significant disciplinary action against it because of its alleged role in a US\$20 billion money-laundering scheme dubbed the Global Laundromat (Harding, Hopkins \& Barr, 2017). It is alleged here that Russian criminal linked to the Kremlin, the KGB and its main successor, the FSB deployed the said scheme between 2010 and 2014 to filter an estimated US\$80 billion into the western financial system. Some seventeen banks based in the UK or with branches in the UK including Coutts, Barclays, Lloyds, Bank of Scotland, and HSBC are facing questions over their knowledge of this scheme, and importantly why they fail to turn away suspicious money transactions (Organized Crime and Corruption Reporting Project (OCCRP), 2014)

It is further alleged that shell companies commonly based in the UK loaned money to one another (Harding, 2017). These then defaulted on their huge fictitious debts that were authenticated by compromised judges in Moldova, culminating in billions transferred to Moldova and the Baltics through a Latvian bank. DB was then subsequently employed to launder the money through its corresponding banking network, thereby effectively enabling illegal Russian payments to be channeled to Asia, the EU, and the US.

Apparently, the bank became aware of this through media reports. Inhouse investigations following the revelation suggested some 1,244 high risk entities in Germany, the UK, and the US. These were said to be responsible for some 700,000 transactions involving at least some US\$47 million in the US, $£ 62$ million in the UK, and $€ 55$ million in Germany (Harding, 2019). SARs were subsequently forwarded to the National Crime Agency in London and to US competent authorities.

These spates of events dented further DB's reputation that was already weakened by earlier police raids on its Frankfurt headquarters over revelations from the Panama Papers. The bank has also been issued a subpoena by the US Congress for submission of documents relating to its lending to the US president. 
DB is, however, no stranger to scandals and settlements with regulator. Between 2015-2017, the bank paid around US\$11.2 billion in fines to regulatory and judicial authorities in the UK and the US for various violations of banking rules that transpired from mid-2000s until recently (Valladares, 2019). The bank's exposure to dubious Russian money remained a regular violation theme (Harding, Hopkins \& Barr, 2019). The UK's FCA fined the bank $f 163$ million for carrying out a US\$10 billion mirror trade scheme conducted out of its branch in Moscow. The New York Department of Financial Services fined the bank some US\$425 million over the same case, where Russian roubles were converted into dollars through fake trades on behalf of its very affluent Russian clients. DB is also under investigation for providing corresponding banking services to the Danske Bank's Estonian branch via its US subsidiary that is alleged to be involved in money laundering. Previous fines paid by the bank are not expected to be the last, as concurrently it is facing four other investigations (Valadares, 2019).

The DB has reportedly terminated business with Moldova's Moldindconbank and Latvia's Trasta Komercbanka, the two banks involved in the Laundromat scandal, and the favourite destinations for illicit Russian money. It has also trimmed down its businesses in Ukraine and Russia. The bank responded to these various sandals by tripling its anti-financial crime personnel since 2015 and sine 2016 has invested 700 million in the upgrading of key control functions. Though the bank has repeatedly mentioned that it takes compliance with money laundering laws seriously, recent events dented its credibility over this claim. Over the past two decades, government authorities have concluded at least five times that DB either failed to police the money flows it handled, or helped to enable initiatives for the evasions of AML (Schoenberg, Hamilton \& Basak, 2019).

These three banks highlighted here are not only European banks involved. Others included France's Societe Generale, PNB Paribas and Credit Agricole, Malta's Pilatus Bank, Estonia's Versonbank, Latvia's ABLV Bank, and UK's Standard Chartered, Royal Bank of Scotland, HSBC, and Barclays (Edwards et al, 2018). Key insights that could be drawn from across these cases suggest that money laundering persist as a main operational risk for banks globally, with European banks being over-represented in anti-money laundering and sanction violations (Edwards et al, 2018). Most of the banks involved have mentioned or promised serious reforms in their AML systems, but these remain to be seen, as equivalent promises have been made before. In immediate response to AML problems in the EU banking sector, the EC accordingly proposed a three-prong approach for reinforcing AML supervision. These pertain to further guidelines and best practices from the European Banking Authority (EBA); enhanced powers for the EBA including an obligation to act as part of the ESA review; and setting up where appropriate an EU body, as part of the review clause of the $5^{\text {th }}$ AMLD in 2022 (Deslandes, Dias \& Magnus, 2019).

\section{Implications of the case findings and other insights for the way forward}

The money laundering scandals in banks in the US, the EU and elsewhere suggest the ineffectiveness of banks as gatekeepers. Scrutiny of gatekeepers' effectiveness in deterring financial crime like money laundering showed the general apathy towards this problem. These failures had been described as the handiwork of a few bad apples (Fleming \& Giles, 2014; Rustin, 2013), but the magnitude of the problem and their recurring (Bray, 2019) suggest oversight failures by regulators (Wolf, 2012), and the failures of corporate governance practices in the banking sector (Yeoh, 2016).

Though most banks for instance claimed compliance to AML rules, in reality most kept breaching them in the relentless pursuits of market share and profitability to stay ahead of competition (Protess, Silver-Greenberg, 2012). The causes of compliance failures are multifaceted. These have been attributed to enforcement deficiencies, difficulties of overseeing compliance systems within complex entities, or failures to set up a culture of compliance throughout the entire entity (Griffith, 2016); in short, a very difficult hurdle. 
Regulatory response to the seriousness of the threat led to fresh or rebooted approaches in the UK (Nakajima, 2019), and lately, the US (2019) too. The DOJ revised its earlier February 2017 Guidance on Evaluation of Corporate Compliance systems on 30 April 2019. The UK had earlier provided guidance on adequate procedures. The US DOJ's guidance tells prosecutors that effectiveness evaluation would entail ascertaining whether an entity's compliance is well-designed, whether its programme is effectively implemented, and third, whether the system works in practice (Hansen \& Baldwin, 2019). This means US entities must ensure that their AML compliance programmes are adapted over time so as to respond to changes in the entity's business. Compliance system's effectiveness could be better achieved through a focus on the compliance process incorporating the distinct, but interrelated phases of prevention, detection, investigation, and remediation (Root, 2019; Vermeulen, 2018). This would lead to the creation, implementation, and better evaluation of compliance systems for policymakers, regulators, and industry leaders.

Conventionally, the approach involves imposing liability on gatekeepers for the wrongs of their corporate clients thereby providing these gatekeepers with the incentives to employ their powers to monitor and to control, or at least influence the conduct of their clientele to deter potential wrongdoings. In practice, various factors could undermine the deterrent force of gatekeeper liability, including the problems posed by misalignment of incentives and complex issues arising from the gatekeepers being beholden to their clients for fees and so on (Tuch, 2017).

Collaborative gatekeeping (Gadinis \& Mangels, 2016) such as through the use of SARs though helpful for banks as a defence could potentially exposed them to defamation liability as happened in one recent case. Here, the court held that SARs were confidential, that banks' disclosures of SARs may cause the bank to commit the offence of tipping off, or the offence of making a disclosure that is likely to prejudice an investigation (Lonsdale v National Westminster Bank, 2018). SARs need some adjustments to ensure effectiveness (Tuch, 2017). This could include reducing the numbers of lowquality reports via enhanced statutory guidance (Thomas, 2018).

Transparency was another troubling issue brought up by the case studies. The Troika Laundromat scandal and its subsequent highlight in the UK Treasury Select Committee (2019) report demonstrated fragmentation in the UK's AML's supervisory approach, but in particular the low visibility of the beneficial ownership companies based in the British Overseas Territories (BOTs) and the UK's Crown Dependencies. Though these places maintain central registers of beneficial ownership, they are accessible only to UK law enforcement and tax authorities, but not the general public. However, with the launching of the Sanctions and AML Act 2018 (SAMLA, 2018) in May 2018, BOTs would be required to implement public registers of beneficial ownership (UK Treasury, 2019)

Consultation on proposals for enhanced disclosures pertaining to crypto assets (Whisker, 2019; Soderberg, 2018), E-money, beneficial ownership, enhanced due diligence, national register of bank account ownership, trust registration service, and so on has begun. Parallel to this, consultation has also commenced on options to enhance the role of Companies House and increase UK corporate entities' transparencies (Department Business, Energy \& Industrial Strategy (DBEIS), 2019). In the matter of enhanced transparency for beneficial ownership, the US too appears to be moving in similar direction as the US Congress indicated that despite delays the bill requiring companies to disclose their beneficial owners at the time of incorporation would move forward (Haggerty, 2019).

Case insights and revelations from parliamentary hearings suggest that whistleblowers played key roles in exposing money laundering. In general, whistleblowers in the EU unlike in the US lacked special legal status to shield them from retaliation by their employers (Alexander, 2018). They are also not provided with significant financial incentives (CFTC, 2019) to offload pertinent information (Yeoh, 2014). In the US, employee confidentiality agreement or non-disclosure agreements (NDAs) prohibiting employees from disclosing potential corporate misconduct to the authorities would violate SEC Rule 21F-17 (Yeoh, 2019; Grugan, 2018). The EU Parliament responded on 16 April 2019 
an approved draft directive for new harmonized rules on whistleblowers' protection. The directive provides EU-wide minimum thresholds to protect persons disclosing information to which they are privy in their work contexts, and that pertains to breaches of EU money laundering laws and so on (Rozier, 2018).

\section{Concluding remarks}

Most banks being listed corporations struggle and compete for profitability to boost their share prices. Case insights suggest that some banks compromised their gatekeeping function when they game AMLs especially European banks with appendages in Eastern Europe, the US, and Asia via the differences and gaps between different jurisdictions. The almost serial money laundering behaviours of some of these banks have induced regulators to enforce stringently against those that do not take their AML compliance functions seriously, and to increasingly looking into holding senior bank officials more accountable. As banking transforms digitally and as cryptocurrencies strive to enter the financial mainstream, banks together with regulators would need to work together as collaborative gatekeepers to deter money laundering in the financial system.

\section{References}

Agarwal, J.D. (2003), "International money laundering in the banking sector", Keynote Address at the Asia Pacific Banker's Congress 2004 in Manila, Philippines on 24 March 2003, https://www.researchgate.net/.../242178742 International Money Laundering in the ...., (accessed 28 April 2019)

Alexander, M. (2018), "Whistleblowers in their own words: What's wrong with UK whistleblowing law and how it needs to change", 18 October 2018, https://www.minhalexander.com/.../whistleblowers-in-their-own-words-whats-wrong-with-u..., (accessed 28 April 2019)

Alexander, R. (1998), "EU: The EC Money Laundering Directive", Journal of Money Laundering Control (JMLC), 2 (1), pp. 68-73

Anderson, T. (2015), "Anti-money laundering: History and current developments", International Journal of Banking Law and Regulation (IJBLR), 30 (2015), pp. 521-531

Basel Institute of Governance (BIG) (2018), "Basel AML Index 2018", BIG 09 October 2018, https://www.baselgovernance.org/sites/default/files/.../basel aml index 1009 2018.pdf, (accessed 28 April 2019)

Beaty, J. \& Gwynne, S.C. (2004), The outlaw bank: A wild ride into the secret heart of BCCl, Washington, D.C., Beard Books

Borlini, L. \& Montanaro, F. (2017), "The evolution of the EU law against criminal finance: The "hardening" of FATF standards within the EU", Georgetown Journal of International Law, 28 (2017), pp. 1009-1062

Bray, C. (2019), "Standard Charted to pay US\$1.1 billion to resolve Iran sanctions investigation", South China Morning Post (SCMP) 9 April 2019, https://www.scmp.com>Business>Companies, (accessed 28 April 2019)

Brockdorff, J. \& Gerybaite, A. (2019), "6 6 th Anti-Money Laundering Directive (6AMLD): A step forward to tax transparency and accountability", KPMG January 2019, https://www.assets.kpmg/content/dam/kpmg/mt/pdf/2019/01/aml6-directive.pdf, (accessed 28 April 2019)

Bruun \& Hjejle (2018), "Report on the non-resident portfolio at Danske Bank's Estonian branch", Bruun \& Hjejle Danske Bank Commissioned Report, 19 September 2018 CFTC (2019), "CFTC announces whistleblower award totaling more than \$2 million", CFTC 4 March 2019, https://www.cftc.gov/PressRoom/PressReleases/7882-19, (accessed 28 April 2019) 
Coffee Jr., J.C. (2006), Gatekeepers: The professions and corporate governance, Oxford, Oxford University Press

Corsoni-Husain, A. \& Savvides, A.M. (2018), "European Union: Adoption of the Fifth Anti-Money Laundering Directive: On 30 May 2018, Directive (EU) 2018/843 amending Directive (EU) 2015/849 on the prevention of the use of the financial system for the purposes of money laundering or terrorist financing, and amending Directives 2009/138/EC and 2013/36/EU (5AMLD) was adopted. The Directive should be transposed into national law by 10 January 2020", Harneys July 2018 13003724, https://www.harneys.com/.../european-union-adoption-of-the-fifth-anti-moneylaundering..., (accessed 28 April 2019)

DBEIS (2019), "Corporate transparency and register reform", DBEIS Consultation Paper May 2019 Deslandes, J., Dias, C. \& Magnus, M. (2019), "Money laundering - Recent cases from a EU banking supervisory perspective", Economic Governance Support Unit Director-General for Internal Policies Paper PE 614.496-February 2019, pp. 1-21

De Vidp, S. (2019), "All that glitters is not gold: The regulation of virtual currencies in the new EU Anti-Money Laundering Directive", DPCE Online, 38 (1), pp. 59-76

https://www.dpceonline.it/index.php/dpceonline/article/view/643, (accessed 28 April 2019) EC (2019), "Anti-money laundering and counter terrorist financing", https://www.ec.europa.eu/.../anti-money-laundering-and-terrorist-financing en, (accessed 28 April 2019)

Edwards, G., Duran, C., Sacchi, F., Ackermann, B. Conversano, L. (2018), “Déjà vu all over again: Money laundering and sanctions woes to continue to haunt Europe's banks", S\&P Global Ratings 16 October 2018,

https://www.allnews.ch/.../ratingsdirect dejavualloveragainmoneylaunderingandsancti..., (accessed 28 April 2019)

EU (2018), "Directives: Directive (EU) 2018/1673 of the European Parliament and of the Council of 23 October 2018 on combating money laundering by criminal law", Official EU Journal 284/22, 12 November 2018

Europa (2018), "Directive (EU) 2018/1673 of the European Parliament and of the Council of 23 October on combating money laundering by criminal law", https://www.eur-lex.europa.eu/legalcontent/EN/TXT/?uri=uriserv:OJ.L .2018.284.01.0022 ..., (accessed 28 April 2019)

European Commission (EC) (2018), "Request to investigate a possible breach of Union law under article 17 of Regulation (EU) No. 1093/2010", EC Letter to EBA, Ref.Ares (2018)4866024-21/09/2018 European Systemic Risk Board (ERSB) (2015), "Report on misconduct risk in the banking sector", ERSB June 2015,

https://www.esrb.europa.eu/pub/pdf/other/150625 report misconduct risk.en.pdf, (accessed 28 April 2019)

Financial Action Task Force (FATF) (2019), "What is money laundering?”, https://www.fatfgafi.org/faq/moneylaundering/, (accessed 28 April 2019)

FATF (2016), "Anti-money laundering and counter-terrorist financing measures: United States, Mutual evaluation report", FATF December 2016,

https://www.fatf.gafi.org/media/fatf/documents/reports/.../MER-United-States-2016.pdf, (accessed 28 April 2019)

Fleiming, S. \& Giles, C. (2014), “City facing more than 'a few bad apples': Scandals like forex probes rubbing salt in wounds, says BOE deputy", Financial Times 28 October 2014, https://www.ft.com/content/24a471b8-5e00-11e4-b7a2-00144feabdc0, (accessed 28 April 2019) Gadinis, S. \& Mangels, C. (2016), “Collaborative gatekeepers", Washington \& Lee Law Review Online, 73 (2016), pp. 797-913 
Gegenheimer, G. (2019), "Consolidated supervision and anti-money laundering compliance: The crossroads of effective banking supervision", Seacen Financial Stability Journal, 1 (2019), pp. 41-54 Griffith, S.J. (2016), "Corporate governance in an era of compliance", William \& Mary Law Review, 57 (2016), pp. 2075-2140

Groysman, I. (2018), "Revolution in crime: How cryptocurrencies have changed the criminal landscape", City University of New York (CUNY) Academic Works John Lay College of Criminal Justice Thesis Fall 12-2018, pp. 1-57

Grugan, T.M. (2018), "Danske Bank money laundering scandal: The tip of the iceberg(s), Money Laundering News 30 November 2018, https://www.moneylaunderingnews.com/2018/.../dannskebank-money-laundering-scandal..., (accessed 28 April 2019)

Haffke, L., Fromberger, M. \& Zimmerman, P. (2019), “Cryptocurrencies and anti-money laundering: The shortcomings of the fifth AML Directive (EU) and how to address them", Journal of Banking Regulation (forthcoming), https://www.doi.org/10.1057/s41261-019-00101-4, (accessed 28 April 2019)

Haggerty, N. (2019), "Despite delays, beneficial ownership bill will move forward: Maloney", American Banker 14 May 2019, https://www.americanbanker.com/news/despite-delays-beneficialownership-bill-will-..., (accessed 15 May 2019)

Hansen, M. \& Baldwin, P. (2019), "Navigating the DOJ's guidance on the evaluation of corporate compliance programmes" The National Law Journal 20 May 2019, https://www.law.com/.../2019/.../navigating-the-dojs-new-guidance-on-the-evaluation-, (accessed 28 April 2019)

Harding, L. (2019), “Deutsche Bank faces action over \$20bn Russian money-laundering scheme: Exclusive: In confidential internal report seen by Guardian, bank says scandal has hurt global brand", Guardian 17 April 2019, https://www.theguardian.com/.../deutsche-bank-faces-action-over-20bnrussian-money..., (accessed 28 April 2019)

Harding, L. (2017), "The global laundromat: How did it work and who benefited?", The Guardian 20 March 2017, https://www.theguardian.com/world/2017/mar/20/the-global-laundramat-how-did-itwork..., (accessed 28 April 2019)

Harding, L., Hopkins, N. \& Barr, C. (2017), "British banks handled vast sums of laundered Russian money: Exclusive: Billions of dollars were moved out of Russia in 'Global Laundromat' operation, with anonymously owned UK companies playing major role", The Guardian 20 March 2017, https://www.theguardian.com/world/2017/mar/2017/british-banks-handled-vast-sums-oflaundered..., (accessed 28 April 2019) Huang, J. Y. (2015), "Effectiveness of US anti-money laundering regulations and the HSBC case study", Journal of Money Laundering Control, 18 (4), pp. 525-532

ING (2018), "ING reaches settlement agreement with Dutch authorities on regulatory issues in the ING Netherlands business", ING Media Statement, 04 September 2018

Jaeger, J. (2018), "ING reaches $\$ 900 \mathrm{M}$ settlement with Dutch authorities", Compliance Week 4 September 2018, https://www.complianceweek.com/ing-reaches-900m-sttlement-

with.../2156.article, (accessed 28 April 2018)

Kraakman, R.H. (1986), "Gatekeepers: The anatomy of a third-party enforcement strategy," Journal of Law, Economics, and Organization, 2 (1986), 53

Lakatos, A.C. \& Hanchet, M.G. (2007), "Confidentiality of suspicious activity report", Journal of Banking Law, October 2007, pp. 794-809

Lonsdale v National Westminster Bank plc [2018] EWHC 1843(QB)

Marria, V. (2018), "The EU's $5^{\text {th }}$ Anti-Money Laundering Directive: What does it mean?" Forbes 13 September 2018, https://www.forbes.com/.../eu-5th-anti-money-laundering-what-does-it-mean..., (accessed 28 April 2019) 
Maximillian, F. \& Teichmann, J. (2017), "Twelve methods of money laundering", Journal of Money Laundering Control, 20 (2), pp. 130-137

Monroe, B. (2016), "FATF chastises U.S. on beneficial ownership, oversight of attorneys, real estate, Swiss on sharing", Association of Certified Financial Crime Specialists (ACFCS) 8 December 2016, https://www.acfcs.org/news/.../FATF-chastises-U.S.-on-neneficial-ownership-oversight..., (accessed 28 April 2019)

Naheem, M.A. (2018), "Illicit financial flows: HSBC case study", Journal of Money Laundering Control, $21(2)$, pp. 231-246

Nakajima, C. (2019), “Corporate failures and governance- The UK government's response”, Company Lawyer, 40 (1), pp. 1-3

Neely, J. (2018), "Danske money laundering scandals widen with DOJ inquiry", Reutters 4 October 2018, https://www.reuters.com/articles/us-danske-bank-money-laundering-timeline/danske-mo..., (accessed 28 April 2019)

Nielsen, J. (2018), "Combating money-laundering in the EU banking system", Opening statement by interim CEO in Danske Bank Jesper Nielsen at the public hearing of the European Parliament's Special Committee on Financial Crimes, Tax Evasion and Tax Avoidance (TAX3), 21 November 2018 Noonan, L. \& Cohen, J.M. (2019), “USA: Anti Money Laundering 2019” in J.M. Cohen \& S. Brooker (eds), The international comparative and legal guide to anti-money laundering 2019, London, Global Legal Group OCCRP (2014), "The Russian laundromat exposed", OCCRP 22 August 2014, https://www.occrp.org/en/laundromat, (accessed 28 April 2019)

O'Connor, D. (2018), "EU Sixth Anti-Money Laundering Directive (6AMLD)- Expert analysis of new measures", KYC360 21 February 2018, https://www.riskscreen.com/kyc360/article/6amld-eu-sixthanti-money-laundering-dire..., (accessed 28 April 2019)

O'Connor, D. (2019), "EU Sixth Anti-Money Laundering Directive (6AMLD): Countdown to enforcement begins" KYC360 25 February 2019, https://www.riskscreen.com/kyc360/article/eusixth-anti-money-laundering-directive-6..., (accessed 28 April 2019)

Osborne, S. (2018), "Brexit news: Another Eurozone bank pilloried for MONEY LAUNDERING: Furious MEPS are calling on eurozone officials to take stronger action after yet another money-laundering scandal at an eastern European bank and have branded the long-running issue an "embarrassment"", Express 31 March 2018, https://www.express.co.uk>News>World, (accessed 28 April 2019) Parket, F. (2018), "ING pays 775 million due to serious shortcomings in money laundering prevention", https://www.om.nl@103952/ing-pays-775-million/, (accessed 28 April 2019) Protess, B. \& Silver-Greenberg, J. (2012), "HSBC to pay $\$ 1.92$ billion to settle charges of money laundering", New York Times 10 December 2012, https://www.dealbook.nytimes.com/.../hsbc-saidto-near-1-9-billion-settlement-over-money-..., (accessed 28 April 2019).

Reuter,P. \& Truman, E.M. (2004), Chasing dirty money: The fight against money laundering, Washington DC, Institute of International Economics Root, V. (2019), "The compliance process", Indiana Law Journal 94 (2019), pp. 203-251 Rozier, V. (2018), "Proposal for a directive- Amendments by the European Parliament to the Commission proposal on the protection of persons reporting on breaches of Union law", COM(2018)0218-C8-0159/2018-2018/0106(COD)) A8-0398/2018

Rustin, S. (2013), "Andrew Tyrie: Fresh from the HBOS debacle, now serious about reform", The Guardian 20 April, 2013, https://www.theguardian.com/business/2013/apr/20/andrew-tyriesbanking-reform, (accessed 28 April 2019)

SAMLA 2018 Chapter 13, https://www.legislation.gov.uk/ukpga/2018/13/contents/enacted, (accessed 28 April 2019) 
Schoenberg, T., Hamilton, J. \& Basak, S. (2019), “Deutsche Bank U.S. unit kept Danske's shady billions flowing", Bloomberg 3 April 2019, https://www.bloomberg.com/news/articles/2019-04-

03/deutsche-bank-s-u-s-unit-kept-danske..., (accessed 28 April 2019)

Shwartzkopff, F. (2019), "Bank secrecy rules get a rethink after Danske laundering shock", Bloomberg 12 March 2019, https://www.bloomberg.com/news/articles/2019-05-12/bank-secrecy-rules-get-arethink, (accesses 28 April 2019)

Soderberg, G. (2018), "Are bitcoin and other crypto-assets money?", Riksbank Paper No. 514 March 2018, pp. 1-14, https://www.riksbanks.se/globalassets/.../are-bitcoin-and-other-crypto-assetsmoney.pdf, (accessed 28 April 2019)

Stempel, J. (2019), "Danske Bank, ex-CEO are sued in U.S. over money laundering scandal", Reuters 10 January 2019, https://www.reuters.com/article/us-danske-bank-lawsuit/danske-bank-ex-ceo-aresued-in..., (accessed 28 April 2019)

Treanor, M.K. (2018), "Recent Nordic scandals involving ING Bank and Danske Bank underscore the European Union's vulnerabilities to money laundering", Ballard Spahr LLP, 6 September 2018, https://www.moneylaunderingnews.com/2018/09-recent-nordic-scandals-involving-ing...,(accessed 28 April 2019)

Ullah, Z. \& Paley, R. (2018), "Sixth anti-money laundering directive-Strengthening the preventive framework", Eversheds Sutherland 26 November 2018, https://www.eversheds-

sutherland.com/global/en/what/articles/index.page?, (accessed 28 April 2019)

US Treasury (2019), "Treasury statement on European Commission list of jurisdictions with strategic AML/CFT deficiencies", US Treasury 13 February 2019,

https://www.home.treasury.gov/index.php/news/press-releases/sm610, (accessed 28 April 2019)

Tuch, A.F. (2017), "The limits of gatekeeper liability" (2017), Washington \& Lee Law Review Online, 73 (2017), pp. 619-640

Thomas, E. (2018), "Race to cap explosive rise in UK's suspicious activity reports", Risk Screen 10

September 2018, https://www.riskscreen.com/.../race-to-cap-the-explsive-rise-in-uks-suspicious-

activity-reports..., (accessed 28 April 2019)

UK Treasury (2019), "Transposition of the Fifth Money Laundering Directive: Consultation", UK Treasury Consultation April 2019

UK Treasury Select Committee (UTSC) (2019), "Economic crime- Anti-Money laundering supervision and sanctions implementation", UTSC Report Twenty-Seventh Report of Session 2017-2019 HC 2010 8 March 2019, pp. 1-87

Valladares, M.R. (2019), “Deutsche Bank needs serious laundering”, Forbes 7 April 2019), https://www.forbes.com/sites/mayrarodriguezvalladares/2019/04/07/deytsche-namk-needs..., (accessed 28 April 2019)

Vermeulen, G. (2018), "Banks as gatekeepers to the financial system: Is it working", https://www.linked.com/.../banks-gatekeepers-financial-system-working-geert-vermeulen...,

(accessed 28 April 2018)

Weld, J. B. (2011), "Current international money laundering trends and ani-money laundering cooperation measures", $146^{\text {th }}$ International Training Course Visiting Experts' Papers Resource Material Series (UNAFEI) No. 83, pp. 37-47,

https://www.unafei.or.jp/publications/pdf/RS No83/No83 08VE Weld3.pdf, (accessed 28 April 2019)

Whisker, J. (2019), "Anti-money laundering and counter-terrorist financing threats posed by mobile money", Journal of Money Laundering Control, 2(1), pp. 158-172

Wilkinson, H. (2018), "Money laundering in the EU banking sector: What is failing?", Initial Statement by Mr. Howard Wilkinson to the European Parliament Special Committee on Financial Crimes, Tax Evasion and Tax Avoidance, 21 November 2018 
Wilkinson, H. (2018a), "Response to questionnaire" Submission by Howard Wilkinson to the European Parliament Special Committee on Financial Crimes, Tax Evasion and Tax Avoidance, 21 November 2018

Wolf, N. (2012), "This global financial fraud and its gatekeepers", The Guardian 15 July 2012, https://www.theguardian.com/commentisfree/2012/.../global-financial-fraud-gatekeepers, (accessed 28 April 2019)

Yeoh, P. (2014), "Whistleblowing: Motivations, corporate self-regulation, and the law", International Journal of Law and Management, 56 (6), pp. 459-474

Yeoh, P. (2019), "Non-disclosure agreements: The keeping silent market controversy", Company Lawyer 2019 Forthcoming

Yeoh, P. (2016), Corporate governance failures and the road to crime", Journal of Financial Crime, 23(1), pp. 216-230

Zagaris, B. (2019), "Money laundering and bank secrecy: Deutsche Bank under investigation in France while Estonia arrests 10 former employees and European Community agrees to increase its financial supervision powers", IELR, 35 (1), pp. 1-8 